\title{
Biblical Spirituality and transformation
}

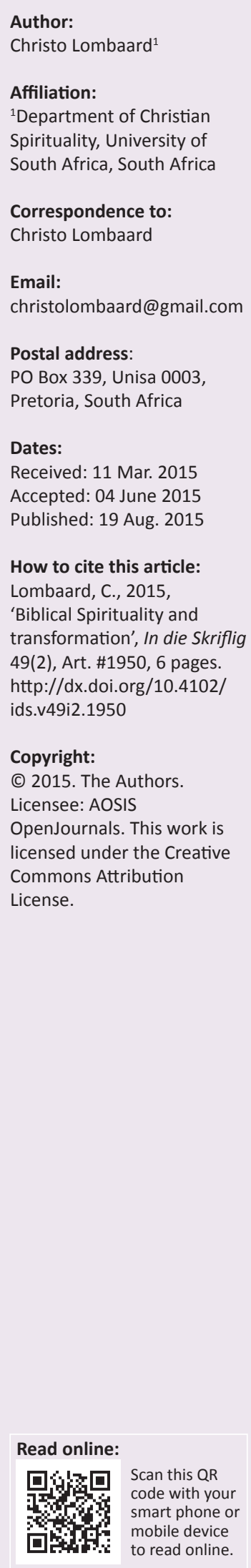

Transformation is one of the key elements of the human spirituality phenomenon and is one of the foundational areas of study within the discipline of Christian Spirituality. Transformation entails the meaningful, deep changes within individuals as they are touched by the Holy and as they mature in their experience of and expression given to their faith. This article places that dynamism within the framework of the academic discipline of Biblical Spirituality, which is briefly described in the first part. After depicting the concept of transformation in some detail, its relationship with and its occurrence in the Bible are outlined.

Bybelse Spiritualiteit en Transformasie. Transformasie is een van die sleutelelemente binne die menslike spiritualiteitsverskynsel en is een van die grondbeginsels van die studieveld binne die Christelike Spiritualiteitskunde. Transformasie behels betekenisvolle en diepgaande verandering in individue namate hulle deur die Heilige aangeraak word, groei in die belewenis van hulle geloof en hoe uitdrukking daaraan gegee word. Hierdie artikel plaas dié dinamiek binne die raamwerk van die akademiese dissipline van die Bybelse Spiritualiteit wat kortliks in die eerste gedeelte beskryf word. Nadat die transformasiekonsep in redelike besonderhede uiteengesit is, word die verwantskap daarvan aan, en die voorkoms daarvan in die Bybel omskryf.

\section{Biblical Spirituality and its recent methodological developments}

Strangely, though spirituality itself remains hardly possible to define (Lombaard 2008:94-107) despite many attempts (cf. Waaijman 2006:1-18; extensively, Waaijman 2000; 2002; 2004; 2005; 2007), one of its interdisciplinary offshoots, Biblical Spirituality, has escaped at least some of this persistent and inherent vagueness. Placed as it is between the methodologically imprecise discipline of Christian Spirituality and the methodologically exacting, and contested, discipline of Bible exegesis (cf. Lombaard 2011a:211-225), this 'in-between' discipline of Biblical Spirituality (cf. Welzen 2011:37-60 for the most recent overview of approaches to Biblical Spirituality as a discipline) has managed, perhaps for precisely the reason of its 'in-between' placement, to escape two problems. Firstly, Biblical Spirituality tends to be methodologically more concrete than the broader discipline of Christian Spirituality within which it is housed. Secondly, Biblical Spirituality finds itself free from the often experienced estrangement from matters of faith of which the Bible sciences have repeatedly stood accused (in my view, unfairly, but also understandably so). In fact, there is a decided sense amongst scholars in the field of Biblical Spirituality that this discipline may lead Old and New Testament studies onto paths more sensitive to religious belief too.

Biblical Spirituality studies two interrelated aspects (cf. Lombaard 2012a:111-137; Schneiders 2000:1-22): how aspects of faith have found expression in the texts that went on to become the Bible texts, and how people have subsequently related to these texts, in faith, or in non-faith, or even in anti-faith orientations. It is these two aspects of the discipline that will broadly guide the structure of the later part of this article, though in reverse order:

- how people relate or have related to the Bible as book of faith; and

- how faith has come to be expressed in the Bible texts.

Natural to the discipline of Biblical Spirituality is also to seek perspectives on a third set of questions that logically result from the interaction between these two aspects: How do these two aspects relate to one another, if at all?

Before such matters are taken into consideration, though, a more direct issue related to the theme of this article has to be addressed: How can it be that the discipline of Biblical Spirituality is at all interested in the topic of transformation? 


\section{Towards transformation}

Apart from setting out its two-directional gaze as indicated above, the discipline of Biblical Spirituality has also been characterised by exploring in different ways how these horizons can be engaged. Staying for the moment with my own explorations in this regard, this includes (here building forth on Lombaard 2012b:1) tracing different spiritualities within the biblical texts (Lombaard 2012a:83-110), and outlining critically how modern interpretations, both individual (Lombaard 2012b:1-5) and institutional (Lombaard 2012a:139-169), have related in contextual faith to the biblical texts (cf. Lombaard 2012a:171-189). Also, then, indicating implicit ways in which exegetes, despite their usual reticence on such matters, nevertheless do try to express in their work the voice of the Divine from a Bible text (Lombaard 2012d). In broadly-cultural scope, modern-ancient parallels in what has become known as post-secularist constructions of faith, may be detected (Lombaard 2012e). On a more thematic level, one may analyse how a spiritual trait such as silence (Lombaard 2012c) or a spiritual process such as discernment (Lombaard 2015a) is encountered in relation to the biblical text. Relating directly to the latter: a further step, developing from discernment, is transformation as a natural next step in the thematic development of the discipline of Biblical Spirituality, as it relates directly to this aspect. This, also with transformation commonly acknowledged as lying at the heart of spirituality (cf. e.g. Waaijman 2002:455-483). Without transformation, spirituality is stagnant (cf. the closing sentence of this article).

It is thus entirely in keeping both with the nature of disciplinary specialisation and with the expansion of a relatively new discipline's horizons, that an extant topic such as transformation can now be explored anew.

Exactly what is meant by transformation is, however, not all that clear.

\section{What is transformation?}

In the South African political landscape the term transformation has been commandeered into the almost exclusive service in racial and gender equality measures of the present government. Although transformation certainly has important dimensions of social justice to it (Fox 1982:76), in the way the term is employed within Spirituality Studies, it has more deeply existential overtones. Transformation, understood within the agenda of spirituality, is an encounter with the Divine that brings about profound change in an individual's relationship with the Holy, to the extent that this changes his or her whole life in such a way that it touches the immediate and the broader social and other circles fundamentally too (Waaijman 2002:456-481 fleshes out these aspects in great detail). Conversion is a term not out of place here as long as it is understood along with its broader range of implications. Altering the outer world follows on such a thoroughgoing interior change: 'Despite its objective and exterior character, religion also promotes, guides, and shapes spirituality in its various forms, but especially in terms of interiority and the quest for self-integration, selftransformation, and self-transcendence' (Pool 2011:9). ${ }^{1}$ God touches the self and - so as not to fall into the confines of pietism, but to acknowledge the extending influence of piety the 'self' changes the world in circles of ripples across various spheres of society.

Although in traditional faith conceptions it must remain entirely possible to confess that the Holy Other can make a society wholly other by direct intervention, it is also completely in line with traditional Christian thinking that God uses people to change the world for the better. As a note of humility, though, such a confession of divine agency by means of human agents (cf. Bragg 1984:157) ought not to be taken with an exclusivist kind of presupposition that God uses only religious people, or, as an even more circumscribed position, only Christians to exert positive influence on the world. Apart from dogmatological categories that could be employed to make such a point, the Old Testament already knows the example of, for instance, Cyrus being called a messiah. This, for the role he is acknowledged by the Isaiah 45 author as having been given (cf. Fried 2002:373-393), namely - depending on one's point of view - through his liberal policies on local religions in his empire, or by Yahweh. In some vaguely parallel way in modern socio-political and religious history, the use of traditionally atheistic, even anti-religious Marxist thinking to create what would become the social justice theologies of recent decades such as Liberation, Black and African Theologies, and in some respects Feminist Theologies (cf. Rowland 1999), could be cited as similar instances of the transformation of established or establishment Christianity internationally towards greater inclusiveness. It seems that neither in antiquity nor in modernity (cf. Shaull 1998:79) are confessions on changes for the good in society and/or theology fully predicated on persons with (what could be termed) orthodox religious commitments.

Nor, however, can the latter be excluded. By no means an uncommon experience for religious people (Smith 2006:293-294), as, for instance, the rarity of a mystic encounter tends to be, a transformational engagement with God is a deeply touching experience with the Divine that alters many people's lives. Transformation is thus not elitist in two senses: it is not limited to the few, and for the many who experience it, it is not limited to themselves. Rather, transformation is open and opening: it is open to many people, who experience their change and growth, the conversion that alters their inner awareness as an openingup towards the Other and the other.

This engagement should therefore not normally be understood as only a single profound occurrence, which of course it could be, as a kind of enlightening (AhaErlebnis), but there psychologically meant (Bühler 1907:14).

1.Possible directive overtones here are not intended as such: religion and spirituality are mutually influencing, related phenomena. 
Most commonly it is an ongoing experience of living in a relationship with God that steers one continuously. To be 'surprised by joy', as formulated in the popular CS Lewis book (1955), is an unfolding experience. Transformation, like life, happens. When recognised for what it is, it can be more fully appreciated, both for its existence and for the value, depth and the growth it adds to one's life-of-faith.

Fullness is therefore another characteristic of transformation, to the point that Bragg (1984), for instance, can propose it as a more all-encompassing concept of traditional societal development models by arguing as follows:

Development that is Christian is transformation of the person and social structures that frees persons and societies to move toward a state of increasing wholeness in harmony with God, with themselves, with others, and with the environment. (p. 165)

Transformation of one's being with God also alters one's being in the world.

This presupposes a depth of engagement with God and creation that becomes increasing averse to superficiality. For instance, to be 'spiritual, but not religious' has become by now a slogan of sorts across the world (yet it is certainly not new - the phrase occurs on academic pages from at least the 1970s) to express something of a sense or perhaps just an image of not being superficially inclined. This, though, without wanting to seem fanatical or be socially ostracised or be expected to be psychologically demanding as a conversation partner. Although this expression may be popular (cf. Fuller 2001; Perrin 2007:44) and in some respects telling (Kourie 2006:24), it has recently been reproached as not making room for the depth required truly to engage meaningfully with life in all respects (Jonkers 2012). Religious bricolage, inherent to all expressions of faith (the line between contextualisation or enculturation and syncretism remains vague and fluid), which becomes the defining characteristic of a 'spiritual, but not religious' life-orientation, can easily become primarily self-oriented, whereas a deeply transformative engagement does not lose its foci on also the Other and the other. As inherently self-implicating, as spirituality by its very nature is (cf. e.g. Schneiders 2005:31), it is also at once not implicitly selfreferential: even when the idea is conveyed of turning into oneself, within Christian spirituality this is meant as finding an Other there. Although popular spirituality may seek to find the divine (usually 'the goddess') within oneself as a kind of feel-good or self-affirming exercise (e.g. Hibberd 2008), the richer traditions of Christian spirituality find their solace in a God that is not the self. I am not 'I am' (cf. Ex 3:14); God is. Even in the mystical moment where, in Christian history, the expression is found that the mystic becomes one with God, which is at times called deification, that is not meant as hubris, where the I (as the individual human) becomes the Divine. Rather, the opposite is meant: that in the presence of God I find myself so wholly overwhelmed, insignificant and humbled, that my being is subsumed wholly in awe of the Holy, as if I disappear, and God is all. The I of the beholder is beholden to the Holy for this experience-of-melting-into-nothingness to occur (on nothingness, cf. Kourie 2008:59-75).

Such (at times ecstatic) transformation too is thus not self-aggrandising, but elevating in the sense of selfrelinquishment coram Deo. The reference point and the universe, the beginning, the end and the all remain God. I am transformed in being transfixed, but in such terminology, the 'trans' implies an Other, the 'Wezer'. In the language of Waaijman (2000): 'the One Who Is'; by implication: the One Who Is Absolutely. Becoming Christ-like (cf. e.g. Rose 2010:11-16, 213-215 for a traditional evangelical take on this concept) does not entail me becoming the Saviour; it means simply that I find myself consumed ever more closely by Christ's example in my relations with God and humanity.

\section{Transformation and the Bible}

The ways in which the Bible effects transformation in the lives of individuals and societies could be analysed from different perspectives. For the most part, such influence would be expected to be discernable within people who hold dear a framework of broad, though diverse, acceptance that the Divine communicates existentially with individuals via the Bible (cf. Attfield 2001) on matters that are foundationally important to their lives. The Bible is thus experienced as being a holy Word that impacts on their lives.

Such influence is, however, also, in some ways, to be detected amongst people outside such circles. The above is not meant to imply that the Bible has no meaning for or effect on the lives of non-religiously inclined people. As stated elsewhere, phenomenologically speaking 'inspiration' for life may be sought in, for instance, any form of good literature (Lombaard 2001:84). Still, the Bible is not excluded from more direct influence. This is seen in, firstly, the popularity also of works such as God bestaat niet en Jezus is zijn zoon (Hendrikse 2011), which follows thematically on, for instance, Comte-Sponville's L'esprit de l'athéisme (2006), to name only two examples. By this is shown, in some way, that the Bible retains importance even for non-religious people, or for differently-religious or non-aligned people who therefore have an interest in the non-religious. The Bible remains at least topically alive in such circles. One can speak at the very least of The Bible as cultural heritage (Beuken \& Freyne 1995).

Secondly, apart from such more personal non-religious interest, which may be vague, the after-effects of the Bible within broader culture can be seen too. This, for instance, may be observed in the day-to-day living of most people of our time (Lombaard 2015b):

God is everywhere: in the new neighbours and the old church buildings, in Hot 100 rock hits as much as in classical choral music, in fashionable jewellery designs and in cool blasphemies, in war and art, in wedding venues and baptism practices and funeral ceremonies, in badly produced televangelism shows one cannot help coming across when scanning through television channels and in ever more popular 
pilgrimage travels, and so forth. This 'everywhereness' of the religious is not experienced as divine omnipresence; though its sources lie far and wide, it is encountered locally and most often unreflectively. (p. 88)

Thirdly, equally unreflectively are foundational concepts upon which modern Western or Westernised societies are built. This includes, for instance, the concept of human rights, which, apart from its ancient roots in Athens on the right to choose political representation, finds in the Jerusalem of antiquity the right to protection of the individual against the state as attested to in biblical texts (cf. Otto 2002; 2004:181188; Van der Ven, Dreyer \& Pieterse 2004 - summarised in Lombaard 2011c:74-93). Here, too, the spiritual inheritance of the Bible influences the experience of full humanity in the Western or Westernised world, even though for the greater part individuals who enjoy the advantages of such a life are unaware of or may even disavow the religious heritage that made this possible. Despite what may be termed such 'quiet whispers' from the Bible into a non- or a-religious world, these influences are nevertheless present - and deeply so. The Bible has had a transformational impact on the lives of individuals and the ordering of societies; also in secular senses; at times to a foundational extent.

Apart from the three instances listed above in which the sphere of the Bible's influence is not experienced as directly related to religious orientations within spheres of faith-full reception of the Bible texts, clearly such influences continue along with other instances too. Primary, here, and fourthly on the list of ways in which the Bible transforms those and that which follows in its wake, is what the Reformers Luther and Calvin respectively referred to as the claritas scripturae and the testimonium Spiritus Sancti internum. The most substantial work in this respect remains that of Rossouw (1963). In the face of frequent misrepresentation throughout the centuries of what these two expressions had meant, their intended and shared insistence that the Bible creates faith in its readership communities stands central (Lombaard 2011b):

This awareness of finding oneself being interpreted, being engaged, being read [by the Bible], namely reciprocally as one encounters the Text, is experienced in such a thoroughgoing way by the recipients as to find their being taken up, redefined, transformed by the event; which may be experienced, alternatively, as: by the Bible; which may yet again be experienced, alternatively, as: by the Divine. (p. 5; [emphases added]; cf. Lombaard 2012a:175)

Such an existential transformation, in which readers encounter the Divine by engaging (in different ways) with the Bible, is something that has remained a constant within mainstream Christianity² (Lombaard 1999:34-35) although in different permutations according to the differing emphases found in the ecumenical world (see recently Kalaitzidis et al. 2014; Werner \& Phiri 2013; Werner et al. 2010; 2013).

2.That is the most influential denominations, as they find presence across the world.

\section{Transformation in the Bible}

Encountering transformation, not only from the Bible, but also in the Bible, is possible in different permutations: within Bible narratives, across biblical themes, through the historical placements of the text, and through mystagogy. The value of such engagement lies therein that examples of transformation within Bible texts can be noticed by readers who then, by means of parallels and analogies, experience these 'examples' as instructive to their lives and life situations. Although academics are well-aware of the philosophicalhermeneutical difficulties involved in such interpretative engagement (Thiselton 1992; 1980), for the most part Bible readers circumvent these intellectual difficulties by means of a different, more directly-applied kind of practical hermeneutics (cf. e.g. West 1997).

To relate these two forms of hermeneutics, other than through reader reception theory with its valid but too one-sided approach of ' $t$ t]he reader is the boss' (Prinsloo 1992:60, with reference to Clines 1990), is no easy matter. En route to such a relation of hermeneutics, though, the permutations mentioned above open up some valuable perspectives. The first of these permutations is the dynamics of the narrative as it unfolds in the telling of the story, which readers reflexively apply to their own unfolding life narratives. This initially narratological approach to exegesis (cf. e.g. Du Rand 1990:367-389) has found fruitful application within, for instance, narrative pastoral therapy (cf. e.g. Landman 1997). The second permutation draws on a substantial familiarity with important transformational themes as they play out across Bible texts (Schneiders 1998:43). Such themes have influentially been identified and described by McGrath (1999:82-109) as relating to the topoi of Feast, Journey, Exile, Struggle, Purification, Internalisation, Desert, Ascent, Darkness-and-light and, lastly, Silence. Each of these topoi becomes a metaphorical frame of reference for the spiritual journey of the Bible reader. A third permutation entails engaging up close and personally with the historically placed and developed texts of the Bible, 'with the minutiae of biblical literature providing the unexpected riches that would feed both the exercise and the academic discipline of Spirituality' (Lombaard 2012a:12). This, not as only an intellectual exercise, but also as a thoroughly lived spirituality, drenched in the (dissimilar) historical situatedness of text and reader (cf. Lombaard 2006:912-925). The fourth and last of the permutations identified here is the mystagogical (cf. Waaijman 2011:1-20), in which Bible texts are read deliberately with a view to searching for the mystical, from which readers are 'educated' in their sensitivities towards the mystical engagement with the Divine and transformational engagement with the world.

From these four permutations of text-reader interactions in which readers find themselves transformed, at times surprisingly so, the existential and practical value of the engagement with Scripture as an act of faith, speak clearly. 


\section{Drawing to a close (encounter)}

In this contribution, the programme was set by the initial description of the nature of the discipline of Biblical Spirituality, which traces impulses of faith along two tracks: how they had found their way into the books of the Bible, and how they find their way between the Bible and its readers in our time. With the central theme of transformation discussed from various angles, its interiority as well as its Exteriority and its exteriority were highlighted. Transformation in relation to the Bible was then considered as far as the non-religious and the religious, the individual and society are concerned. The influence of the Bible in transforming those in its wake could hence be indicated in multiple ways. The same could be done as far as transformation within the Bible is concerned, with different permutations indicated. In these ways, the close encounter which individuals experience with the Divine, and how it affects them and the world in which they live, could be explored. These encounters are not separated from the Bible text, either as a medium of religious communication with substantive personal importance, or as a cultural-historical artefact with an enduring heritage. Whether as a Book of faith held existentially dear, or as a book of faith narratives held as historically significant, the influence of the Bible is not closed, but close. Transformations continue.

\section{Acknowledgements}

This article, which finds its origins in a presentation at the Marburger Bibelseminar (www.mbs-akademie.de) on 07 November 2012, is offered here in altered form in honour of Prof. Jan du Rand. As a Master's student in Communication at the then Randse Afrikaanse Universiteit, now University of Johannesburg, I had decided to study Theology, and I found myself in the Biblical Studies class of Jan du Rand and his colleagues. I was invited to be Du Rand's research assistant; the major project then was his Johannine Perspectives (1994). Du Rand forgave me all my idiocies and idiosyncrasies, and I learnt from him during those two years (1990-1991) what research meant: the sacrifices, the joys and the meaningful contributions to human understanding to which true academics aspire. There were others too who had influenced me strongly along the way. Du Rand's influence, though, was the beginnings of my research. Simply by way of his example, his dedication and his relentless research work: thoroughgoing Bible analysis, with always implied the service of faith. This is why I chose this work of mine specifically for his dedication volume. For showing me this world in which I could immerse myself existentially and professionally, how can I ever thank you enough, Jan?

\section{Competing interests}

The author declares that he has no financial or personal relationship(s) that may have inappropriately influenced him in writing this article.

\section{References}

Attfield, D.G., 2001, Proclaiming the Gospel in a secular age. A general theory of religious communication, Ashgate, Aldershot.
Beuken, W. \& Freyne, S. (eds.), 1995, The Bible as cultural heritage, SCM Press, London.

Bragg, W.G., 1984, 'Beyond development to transformation', International Review of Mission 73(290), 153-165. http://dx.doi.org/10.1111/j.1758-6631.1984. tb03262.x

Bühler, K., 1907, Tatsache und Probleme zu einer Psychologie der Denkvorgänge. Über Gedanken, Wilhelm Engelmann, Leipzig. (Archiv für die gesamte Psychologie, 9).

Clines, D.J.S., 1990, What does Eve do to help? And other readerly questions to the Old Testament, JSOT Press, Sheffield.

Comte-Sponville, A., 2006, L'esprit de l'athéisme. Introduction à une spiritualité sans Dieu, Éditions Albin Michel, Paris.

Du Rand, J.A., 1990, 'Narratological perspectives on John 13:1-38', Hervormde Teologiese Studies 46(3), 367-389. http://dx.doi.org/10.4102/hts.v46i3.2325

Du Rand, J.A., 1994, Johannine perspectives. Introduction to the Johannine writings, Orion, Johannesburg.

Fox, M., 1982, 'Creative teaching. Educating for transformation: The spiritual task', Horizons $9(1), 74-80$

Fried, L.S., 2002, 'Cyrus the Messiah? The historical background to Isaiah 45:1' Harvard Theological Review 95(4), 373-393. http://dx.doi.org/10.1017/ S0017816002000251

Fuller, R.C., 2001, Spiritual but not religious. Understanding unchurched America Oxford University Press, Oxford. http://dx.doi.org/10.1093/0195146808. 001.0001

Hendrikse, K., 2011, God bestaat niet en Jezus is zijn zoon, Nieuw Amsterdam, Amsterdam.

Hibberd, D., 2008, How to find the goddess in you, FBF Media, Greystanes, New South Wales.

Jonkers, P., 2012, 'Tradition, religious experience, and personal commitment', main paper presented at the Religious Experience and Tradition International Interdisciplinary Conference, Vytautas Magnus University, Kaunas, Lithuania, 11th May.

Kalaitzidis, P., FitzGerald, T., Hovorun, C., Pekridou, A., Asproulis, N., Liagre, G. et al., (eds.), 2014, Orthodox handbook on ecumenism, Regnum Press International, Oxford.

Kourie, C., 2006, 'The "turn" to spirituality', in P. de Villiers, C. Kourie \& C. Lombaard (eds.), The Spirit that moves: Orientation and issues in spirituality (Acta Theologica suppl. ser. 8), pp. 19-38, University of the Free State Press, Bloemfontein.

Kourie, C., 2008, 'Mysticism: A way of unknowing', in P. De Villiers, C. Kourie \& C. Lombaard (eds.), The Spirit that empowers. Perspectives on spirituality (Acta Theologica suppl. ser. 11), pp. 59-75, University of the Free State Press, Bloemfontein.

Landman, C., 1997, 'Doing narrative counselling in the context of township spiritualities', DTh dissertation, University of South Africa, Pretoria.

Lewis, C.S., 1955, Surprised by Joy: The shape of my early life, G. Bles, London.

Lombaard, C., 1999, 'Ecumenism and the Bible', in C. Lombaard (ed.), Essays and exercises in ecumenism, pp. 26-41, Cluster Publications, Pietermaritzburg.

Lombaard, C., 2001, 'The Bible in the apartheid debate', in J.W. Hofmeyr, C.J.S. Lombaard \& P.J. Maritz (eds.), $1948+50$ years. Theology, apartheid and church: Past, present and future, vol. 1, pp. 69-87, Institute for Missiological and Ecumenical Research (IMER), University of Pretoria, Pretoria. (Perspectives on the Church/Perspektiewe op die Kerk, 5).

Lombaard, C., 2006, 'Teks en mens. J.H. le Roux se lees van die Bybel binne die konteks van hoofstroom-eksegese in Suid-Afrika', Old Testament Essays 19(3), 912-925.

Lombaard, C., 2008, 'Spirituality: Sense and gist. On meaning, God and being', in P. de Villiers, C. Kourie \& C. Lombaard (eds.), The spirit that empowers: Perspectives on spirituality (Acta Theologica suppl. ser. 11), pp. 94-107, University of the Free State Press, Bloemfontein.

Lombaard, C., 2011a, 'Biblical Spirituality and interdisciplinarity: The discipline at cross-methodological intersection', Religion \& Theology 18, 211-225. http:// dx.doi.org/10.1163/157430111X613737

Lombaard, C., 2011b, 'The mystifying mosaic of Moses: On Pentateuch theory and Biblical Spirituality', HTS Theological Studies 67(3), 1-5. http://dx.doi. org/10.4102/hts.v67i3.1121

Lombaard, C., 2011c, 'Biblical Spirituality and human rights', Old Testament Essays 24(1), 74-93.

Lombaard, C., 2012a. The Old Testament and Christian Spirituality. Theoretical and practical essays from a South African perspective, Society of Biblical Literature, Atlanta, Georgia, viewed n.d., from http://ivbs.sbl-site.org/uploads/SBL\%20 book20(final\%20edit).pdf (International Voices in Biblical Studies, 2).

Lombaard, C., 2012b, 'Biblical Spirituality and J.H. Eaton', Verbum et Ecclesia 33(1), 1-5. http://dx.doi.org/10.4102/ve.v33i1.685

Lombaard, C., 2012c, 'Om die Skrif tot stilte te bring ... Gewaarwordinge oor Afrikaanse Bybelse spiritualiteit', Litnet Akademies (Godsdienswetenskappe) 9(3), 929-951, viewed n.d., from http://litnet.co.za/assets/pdf/Lombaard_9_3_GOW1.pdf

Lombaard, C., 2012d, 'Biblical Spirituality, the Psalms, and identification with the suffering of the poor: A contribution to the recent African discussion on Psalm 109', Scriptura 110, 273-281. http://dx.doi.org/10.7833/110-0-116

Lombaard, C., 2012e, ‘Un/modern post-secularism: Now you see God ... now you don't! - The non/absence of God as characteristic of post-secular faith in the modern world, in some Wisdom Writings of the Hebrew Bible and in some key moments from Christian spirituality history', paper presented at the Faculty of Theology, Åbo Akademi University, Turku, Finland, 31st October.

Lombaard, C., 2015a, 'Discernment in Nehemiah 8: Milieu and wake', Journal for the Study of Religion, [Volume and page numbers is yet unknown]. 
Lombaard, C., 2015b, "And never the twain shall meet?" Post-secularism as newly unfolding religio-cultural phase and Wisdom as ancient Israelite phenomenon Spiritualities and implications compared and contrasted', Journal of Theology for Southern Africa 152, 82-95.

McGrath, A.E., 1999, Christian Spirituality. An introduction, Blackwell, Oxford.

Otto, E., 2002, Gottes recht als Menschenrecht. Rechts- und literaturhistorische Studien zum Deuteronomium, Harrassowitz Verlag, Wiesbaden. (Beihefte zur Zeitschrift für altorientalische und biblische Rechtsgeschichte, Band 2).

Otto, E., 2004. “'Wer wenig im Leben hat, soll viel im Recht haben”. Die kulturhistorische Bedeutung der Hebräischen Bibel für eine moderne Sozialethik', in B. Levinson \& E. Otto (eds.), Recht und Ethik im Alten Testament, pp. 181-188, LIT Verlag, Münster. (Altes Testament und Moderne, 13).

Perrin, D.B., 2007, Studying Christian Spirituality, Routledge, London.

Pool, J.B., 2011, 'Toward spirituality of post-Christian Disciples of Jesus', Communio Viatorum 53(1), 3-64.

Prinsloo, W.S., 1992, 'Perspektiewe op die stand van die Ou-Testamentiese wetenskap in Groot Brittanje', Skrif en Kerk 13(1), 56-64. http://dx.doi.org/10.4102/ ve.v13i1.1047

Rose, C., 2010, Transformed into his image. What is means to be like Jesus Christ, reNEW Publication, Castle Rock.

Rossouw, H.W., 1963, 'Klaarheid en interpretasie. Enkele probleemhistoriese gesigspunte in verband met die leer van die duidelikheid van die Heilige Skrif', DTh-proefskrif, Vrije Universiteit, Amsterdam, Drukkerij en uitgeverij Jacob van Campen N.V., Amsterdam.

Rowland, C. (ed.), 1999, The Cambridge companion to liberation theology, Cambridge University Press, Cambridge. http://dx.doi.org/10.1017/CCOL0521461448

Schneiders, S., 1998, 'The Study of Christian Spirituality: Contours and dynamics of the discipline', Studies in Spirituality 8, 38-57. http://dx.doi.org/10.2143/ SIS.8.0.2004088

Schneiders, S., 2000, 'Biblical foundations of Spirituality', in E.J. Mahoney (ed.), Scripture as the soul of theology, pp. 1-22, Liturgical Press, Collegeville, MN.

Schneiders, S., 2005, 'Approaches to the study of Christian Spirituality', in A. Holder (ed.), The Blackwell companion to Christian Spirituality, pp. 15-33, Blackwell Publishing, Oxford. http://dx.doi.org/10.1002/9780470996713.ch2

Shaull, R., 1998, 'From academic research to spiritual transformation: Reflections on a study of Pentecostalism in Brazil', PNEUMA: The Journal of the Society for Pentecostal Studies 20(1), 71-84. http://dx.doi.org/ 10.1163/157007498X00063
Smith, T.W., 2006, 'The national spiritual transformation study', Journal for the Scientific Study of Religion 45(2), 283-296. http://dx.doi.org/10.1111/j.14685906.2006.00306.

Thiselton, A.C., 1980, The two horizons, PaterNoster, Exeter.

Thiselton, A.C., 1992, New horizons in hermeneutics, Zondervan, Grand Rapids.

Van der Ven, H.A., Dreyer, J.S. \& Pieterse, H.J.C., 2004, Is there a God of human rights? The complex relationship between human rights and religion. A South African case, Brill, Leiden.

Waaijman, K., 2000, Spiritualiteit: Vormen, grondslagen, patronen. Carmelitana, Gent.

Waaijman, K., 2002, Spirituality. Forms, foundations, methods, Peeters, Dudley, MA.

Waaijman, K., 2004, Handbuch der Spiritualität, Band 1, Matthias-Grünewald-Verlag, Mainz.

Waaijman, K., 2005, Handbuch der Spiritualität, Band 2, Matthias-Grünewald-Verlag, Mainz.

Waaijman, K., 2006, 'What is spirituality?', in P. de Villiers, C. Kourie \& C. Lombaard (eds.), The Spirit that moves. Orientation and issues in spirituality, (Acta Theologica suppl. ser. 8), pp. 1-18, University of the Free State Press, Bloemfontein.

Waaijman, K., 2007, Handbuch der Spiritualität, Band 3, Matthias-Grünewald-Verlag, Mainz.

Waaijman, K., 2011, 'Biblical Spirituality: An "other" reading (allègoria)', in P. de Villiers \& L. Pietersen (eds.), The Spirit that inspires. Perspectives on Biblical Spirituality (Acta Theologica suppl. ser. 15), pp. 1-20, University of the Free State Press, Bloemfontein. http://dx.doi.org/10.4314/actat.v31i1s.2

Welzen, H., 2011, 'Contours of Biblical Spirituality as a discipline', in P. de Villiers \& L. Pietersen (eds.), The Spirit that inspires. Perspectives on Biblical Spirituality (Acta Theologica suppl. ser. 15), pp. 37-60, University of the Free State Press, Bloemfontein. http://dx.doi.org/10.4314/actat.v31i1s.4

Werner, D., Esterline, D., Kang, N. \& Raja, J. (eds.), 2010, The handbook of theological education in world Christianity. Theological perspectives, ecumenical trends, regional surveys, Regnum Press International, Oxford.

Werner, D., Antone, H., Longchar, W. \& Bae, H. (eds.), 2013, Asian handbook for theological education and ecumenism, Regnum Press International, Oxford.

Werner, D. \& Phiri, I. (eds.), 2013, Handbook of theological education in Africa, Regnum Press International, Oxford.

West, G.O., 1997, The academy of the poor: Towards a dialogical reading of the Bible, JSOT Press, Sheffield. 